\title{
Financial Performance using Ratio Analysis In Hyundai Motors India Limited, Chennai
}

\author{
Magadalene Peter, S.Fabiyola Kavitha, Mary Linda I
}

\begin{abstract}
Hyundai Motor India Limited is India"s driving exporter of traveler autos with a piece of the overall industry of 48 percent of the complete fares of traveler vehicles from India. With a prime goal to satisfy the necessities of broadened clients, the organization has been consistently offering assortment of its brands with inventive highlights to Indian clients. Since origin, Hyundai Motors India Limited has overwhelmed the car showcase with the notoriety of being the quickest developing car producer in India. By and by, Hyundai Motor is considered as the biggest exporter of vehicles to European nations. The object of this paper is to assess the presentation of Hyundai Motors India Limited as for Domestic Sales, Export, Profit after duty, Production[1],[3],[5]
\end{abstract}

Keywords : performance analysis,finance

\section{INTRODUCTION}

Money related Management is that administrative action which is worried about the arranging and controlling of the association's budgetary assets. In spite of the fact that it was a part of financial aspects till 1890 as a different or order it is of ongoing source. [2 ],[4],[6]

Money related Management is worried about the obligations of the account chief in a business firm. He performs such differed errands as planning, money related determining, money the executives, credit organization, venture investigation and assets obtainment. The ongoing pattern towards globalization of business movement has made new requests and openings in administrative fund. [7],[ 9] ,[11] Fiscal reports are arranged and introduced for the outer clients of bookkeeping data. As these announcements are utilized by speculators and money related experts to inspect the company's exhibition so as to settle on venture choices, they ought to be arranged in all respects cautiously and contain as much venture choices, they ought to be arranged all around cautiously and contain however much data as could reasonably be expected. Arrangement of the budget report is the duty of top administration. The fiscal summaries are commonly arranged from the bookkeeping records kept up by the firm.

Revised Manuscript Received on July 22, 2019.

Magdalene Peter, Department of MBA, Bharath Institute of Higher Education and Research, Tamilnadu, India. Email: magdalene.bsb@gmail.com Dr.S.Fabiyola Kavitha, Department of MBA, Bharath Institute of Higher Education and Research, Tamilnadu, India. Email: fabiyolakavitha@gmail.com

MNary Linda I, Department of CSE, Bharath Institute of Higher Education and Research, Tamilnadu, India.. Email: catchlin.18@gmail.com
Money related execution is a significant perspective which impacts the long haul security, benefit and liquidity of an association. Generally, budgetary proportions are said to be the parameters of the monetary presentation. The Evaluation of money related execution had been taken up for the investigation with "Hyundai Motors India restricted" as the venture.

Investigation of Financial exhibitions are of more prominent help with finding the shaky areas at the Hyundai Motors India constrained despite the fact that the general execution might be agreeable. This further aides in [8],[ 10] ,[12]

- Financial guaging and arranging.

- Communicate the quality and money related remaining of the Hyundai Motors India constrained.

- For compelling control of business.

\section{METHODOLOGY}

The venture assesses the budgetary exhibition one of the organization with assistance of the most suitable device of money related examination like proportion investigation and similar asset report. Thus, it is basically actuality discovering study[13], [15],[17]

\section{A.Primary Data:}

Essential information is the direct data that is gathered during the time of research. Essential information has been gathered through exchanges held with the staffs in the records office. A few kinds of data were assembled through oral discussions with the clerk, tax collection official and so forth. [14],[ 16], [18]

\section{B.Secondary Data:}

Optional information considers entire organization records and friends' accounting report in which the task work has been finished. Moreover, various reference books, diaries and reports were likewise used to plan the hypothetical model for the examination. Furthermore, some data were additionally drawn from the sites. [19],[21],[23]

C. Period of study:

The study covers the period of 2006-2007 to 2010-2011 in Hyundai Motors India Limited. [20], [22], [24] 
III. DATA ANALYSIS AND INTERPRETATION

\section{Table:1 Current Ratio}

\begin{tabular}{|l|l|l|l|}
\hline & $\begin{array}{l}\text { Current Ratio } \\
\text { Rs. in lakhs }\end{array}$ & $\begin{array}{l}\text { Current Liabilities } \\
\text { Rs. in lakhs }\end{array}$ & Ratio \\
\hline $2006-2007$ & 9956.81 & 775.49 & 12.83 \\
$2007-2008$ & 8825.79 & 644.26 & 13.69 \\
$2008-2009$ & 9726.73 & 1154.12 & 8.43 \\
$2009-2010$ & 9884.64 & 1501.76 & 6.56 \\
$2010-2011$ & 11949.47 & 3905.45 & 3.06 \\
\hline
\end{tabular}

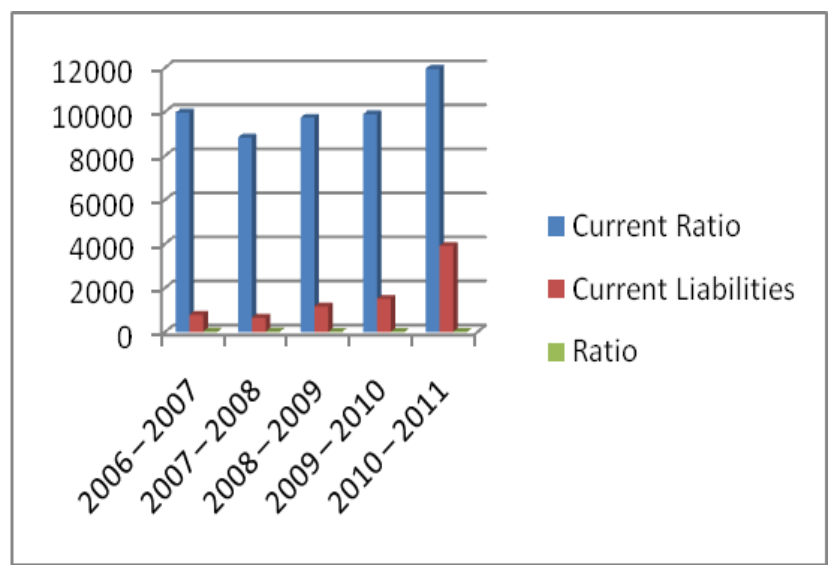

Fig:1 CURRENT RATIO

Table:2 Cash ratio

\begin{tabular}{|l|l|l|l|}
\hline Year & $\begin{array}{l}\text { Cash in Hand \& at } \\
\text { Bank } \\
\text { Rs. in lakhs }\end{array}$ & $\begin{array}{l}\text { Current Liabilities } \\
\text { Rs. in lakhs }\end{array}$ & Ratio \\
\hline $2006-2007$ & 130.54 & 775.49 & 0.17 \\
$2007-2008$ & 141.15 & 644.26 & 0.22 \\
$2008-2009$ & 46.11 & 1154.12 & 0.04 \\
$2009-2010$ & 34.43 & 1501.76 & 0.02 \\
$2010-2011$ & 82.12 & 3905.45 & 0.02
\end{tabular}

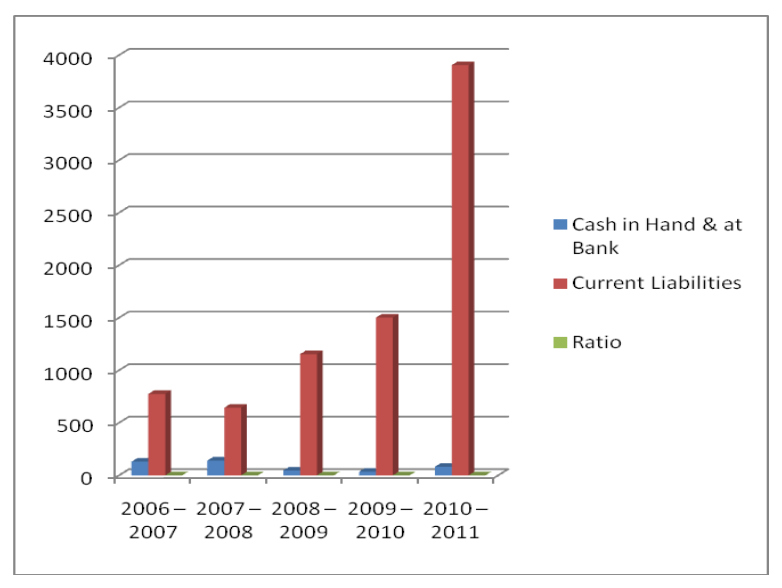

Fig:2 Cash Ratio

Table:3 Average Collection period

\begin{tabular}{|l|l|l|l|}
\hline Year & Days & $\begin{array}{l}\text { Debtors Tumover Ratio } \\
\text { Rs. in lakhs }\end{array}$ & Days \\
\hline $2006-2007$ & 360 & 4211.03 & 0.09 \\
$2007-2008$ & 360 & 3100.98 & 0.12 \\
$2008-2009$ & 360 & 4405.70 & 0.08 \\
$2009-2010$ & 360 & 3524.79 & 0.10 \\
$2010-2011$ & 360 & 3667.52 & 0.10 \\
\hline
\end{tabular}

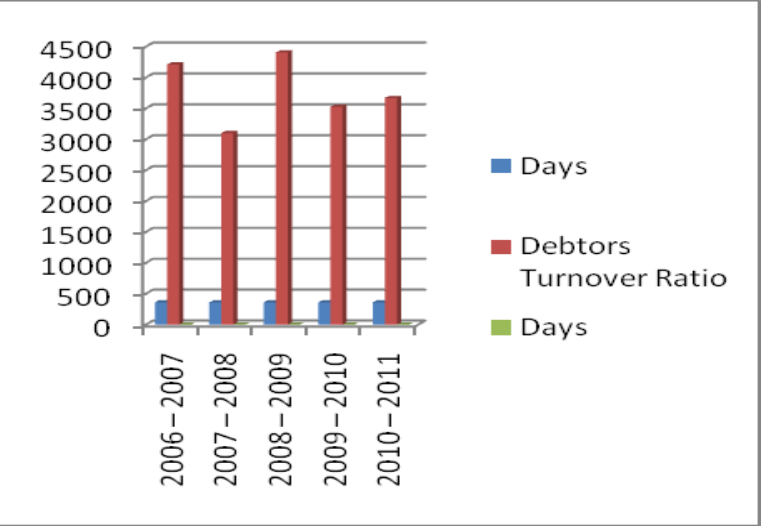

Fig:3 Average Collection Period 
Table:4 INVENTORY TURNOVER RATIO

\begin{tabular}{|l|l|l|l|}
\hline Year & $\begin{array}{l}\text { Cost of goods sold } \\
\text { Rs. in lakhs }\end{array}$ & $\begin{array}{l}\text { Average Inventory } \\
\text { Rs. in lakhs }\end{array}$ & Ratio \\
\hline $2006-2007$ & 11209.73 & 3732.19 & 3.0 \\
$2007-2008$ & 11939.46 & 3508.00 & 3.4 \\
$2008-2009$ & 13708.36 & 3537.44 & 3.88 \\
$2009-2010$ & 12609.33 & 3385.92 & 3.72 \\
\hline
\end{tabular}

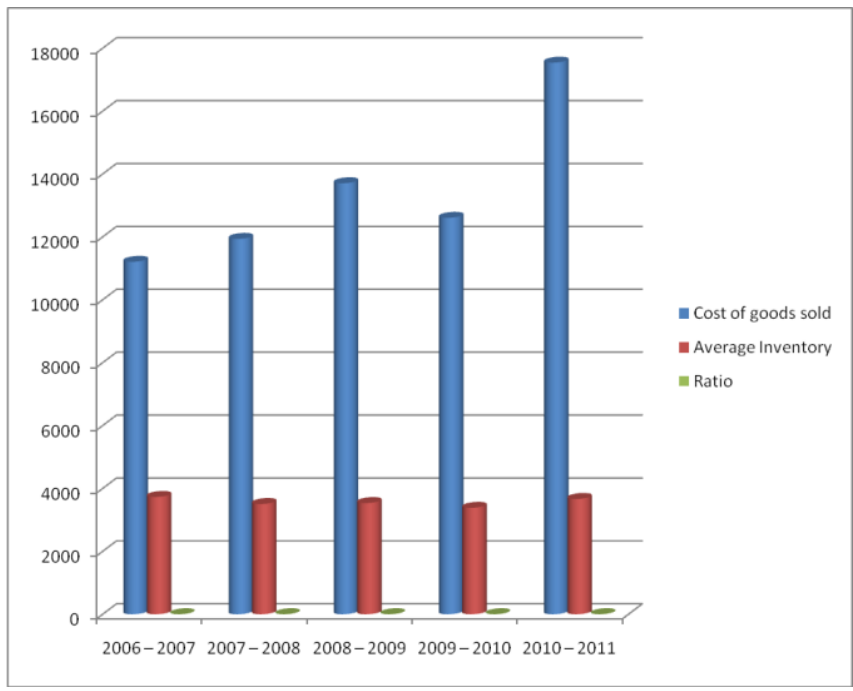

Fig:4 INVENTORY TURNOVER RATIO

Table:5 WORKING CAPITAL TURNOVER RATIO

\begin{tabular}{|l|l|l|l|}
\hline Year & $\begin{array}{l}\text { Sales } \\
\text { Rs. in lakhs }\end{array}$ & $\begin{array}{l}\text { Net Working Capital } \\
\text { Rs. in lakhs }\end{array}$ & Ratio \\
\hline $2006-2007$ & 18262.60 & 9181.32 & 1.99 \\
$2007-2008$ & 19808.5 & 8181.53 & 2.42 \\
$2008-2009$ & 21612.94 & 8572.61 & 2.52 \\
$2009-2010$ & 21885.20 & 8382.88 & 2.61 \\
$2010-2011$ & 30087.56 & 8044.02 & 3.74 \\
\hline
\end{tabular}

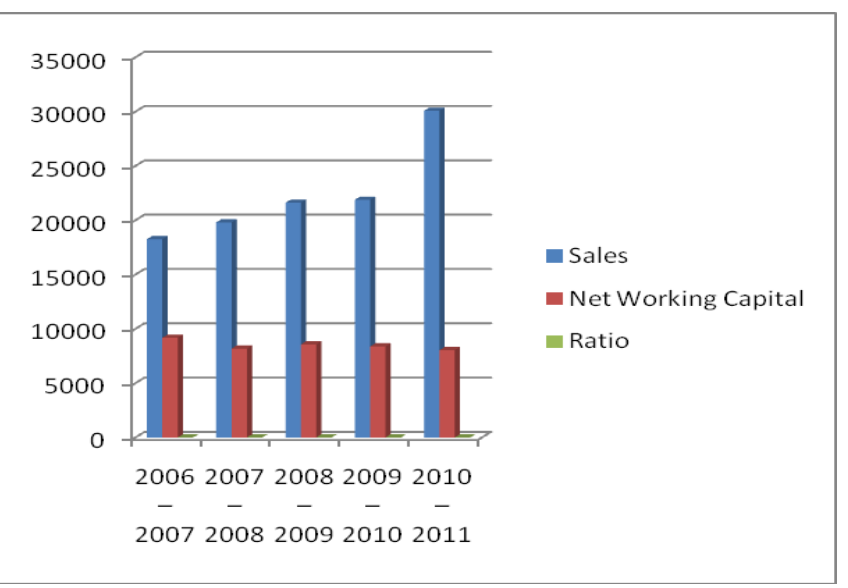

Fig:5 WORKING CAPITAL TURNOVER RATIO

Table: 6 Comparative Balance Sheet as on $31^{\text {st }}$ March $2008-2009$

\begin{tabular}{|c|c|c|c|c|}
\hline Particulars & $\begin{array}{l}31^{\text {st }} \text { March } \\
2008 \\
\text { Rs. in lakhs }\end{array}$ & $\begin{array}{l}31^{\text {st }} \text { March } \\
2009 \\
\text { Rs. in lakhs }\end{array}$ & $\begin{array}{l}\text { Change in } \\
\text { Absolute } \\
\text { Figure } \\
\text { Rs. in lakhs }\end{array}$ & $\begin{array}{l}\text { Percentage } \\
\text { Increase or } \\
\text { Decrease }\end{array}$ \\
\hline Fixed Assets (A & 23599.92 & 23293.33 & $(306.59)$ & 1.30 \\
\hline Investment ( B ) & 812.09 & 690.78 & $(121.31)$ & 14.94 \\
\hline \multicolumn{5}{|l|}{ Current Assets : } \\
\hline Total current Assets (C) & 8825.79 & 9726.73 & 900.94 & 10.21 \\
\hline Total Assets $(A+B+C)$ & 33237.8 & 33710.84 & 473.04 & 1.42 \\
\hline \multicolumn{5}{|l|}{ Shareholders Funds : } \\
\hline Shareholders & 27965.27 & 28335.09 & 369.82 & 1.32 \\
\hline \multicolumn{5}{|l|}{ Loan Funds : } \\
\hline Total Loan Funds ( B ) & 4628.27 & 4221.63 & $(406.64)$ & 8.79 \\
\hline Current Liabilities and & 644.26 & 1154.12 & 509.86 & 79.14 \\
\hline Total Liabilities $(\mathrm{A}+\mathrm{B}+\mathrm{C})$ & 33237.8 & 33710.84 & 473.04 & 1.42 \\
\hline
\end{tabular}

\section{RESULTS AND DISCUSSION}

1.The liquidity position of the organization can be used in a superior or other successful reason.

2. The organization can be utilize the credit offices given by the lenders.

3. The obligation capital isn't used adequately and proficiently. So the organization can expand its obligation capital.

4. Efforts ought to be taken to build the general productivity consequently out of capital utilized by making utilized of the accessible asset adequately.

5. The organization can expand its wellsprings of assets to make powerful innovative work framework for more benefits in the years to come.

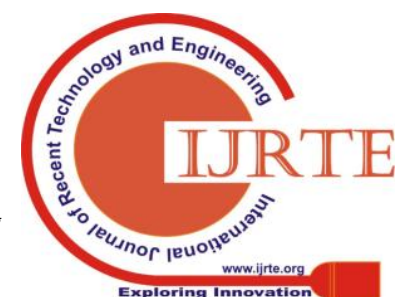




\section{V.CONCLUSION}

- The examination is made on the theme monetary execution utilizing proportion investigation with five years information in Hyundai Motors India Limited.

- The present and fluid proportion demonstrates the transient budgetary position of Hyundai Motors India Limited though obligation value and exclusive proportions demonstrates the long haul money related position. [25],[27],[29]

- Correspondingly, movement proportions and productivity proportions are useful in assessing the effectiveness of execution in Hyundai Motors India Limited. [26],[28],[30]

- The money related execution of the organization for the five years is broke down and it is demonstrated that the organization is monetarily stable. [31],[33],[32]

\section{REFERENCES}

1. G BharthVajan R., Ramachandran S.,Psychographic dimensions of training,2016,International Journal of Pharmacy and Technology,V-8,I-4,P-23727-23729

2. Balakrishnan P., Bharthvajan R.,A study on human resource planning in hospitals in Chennai City,2014,International Journal of Applied Engineering Research,V-9,I-22,P-7503-7507

3. Priyadarsini P., Bharthvajan R.,Role of emotional intelligence training programme in reducing the stress of the nurses,2014,International Journal of Applied Engineering Research,V-9,I-22,P-7411-7421

4. Kerinab Beenu G., Bharthvajan R.,Empirical analysis on the cosmetic buying behavior of young women in South India,2014,International Journal of Applied Engineering Research,V-9,I-22,P-7361-7366

5. Balakrishnan P., Bharthvajan R.,Whistling in the wind,2014,International Journal of Applied Engineering Research,V-9,I-22,P-7586-7593

6. Krishnan B., Peter M.,Health hazards of Indian Bpo employee-an alarming issue,2014,International Journal of Applied Engineering Research,V-9,I-22,P-7336-7341

7. Kerinab Beenu G.H., Peter M.,Role of insurance in economic development,2014,International Journal of Applied Engineering Research,V-9,I-22,P-7532-7539

8. Balakrishnan P., Peter M., Priyadarsini P.,Efficiency of safety measures for wellbeing of employees in manufacturing industry,2014,International Journal of Applied Engineering Research,V-9,I-22,P-7376-7382

9. Anbarasi M., Praveen Kumar S.,Online sales promotions of herbal products and its effectiveness towards tanisha.com,2019,Indian Journal of Public Health Research and Development,V-10,I-1,P-195-200

10. Anbarasi M., Praveen Kumar S.,Various online marketing and promotions strategies to improve the validation towards the organic products in the pharmaceutical sectors,2019,Indian Journal of Public Health Research and Development,V-10,I-1,P-263-269

11. Loganathan R., Praveen Kumar S.,Grievance handling a key factor for solving issues of employees in an organization,2014,International Journal of Applied Engineering Research,V-9,I-22,P-7483-7491

12. Loganathan R., Praveen Kumar S.,Study on preference of private label brands in super and Hypermarkets,2014,International Journal of Applied Engineering Research,V-9,I-22,P-7327-7335

13. Smitha M., Praveen Kumar S.,Understanding stress and its managementamong the nurses in Chennai city,2014,International Journal of Applied Engineering Research,V-9,I-22,P-7560-7565

14. Kerinab Beenu G.H., Praveen Kumar S.,A study on the investment behavior of Chennai investors in mutual fund schemes,2014,International Journal of Applied Engineering Research,V-9,I-22,P-7520-7525

15. Loganathan R., Praveen Kumar S.,Retention strategies key for organizational productivity,2014,International Journal of Applied Engineering Research,V-9,I-22,P-7443-7447

16. Pavithra J., Ganesan M., Brindha G.,State wise analysis of microfinance sector in India,2016,International Journal of Pharmacy and Technology,V-8,I-4,P-23417-23432

17. Pavithra J., Ganesan M.,A comparative study on microfinance in India and abroad,2016,International Journal of Applied Business and Economic Research,V-14,I-8,P-5471-5476
18. Pavithra J., Ganesan M.,A study on awareness and impact of micro-financial schemes,2016,International Journal of Applied Business and Economic Research,V-14,I-8,P-5449-5460

19. Senthilmurugan P., Pavithra J.,Consumer preference towards organised retailing with reference to Big Bazaar,2014,International Journal of Applied Engineering Research,V-9,I-22,P-7469-7475

20. Senthilmurugan P., Pavithra J.,Implication of social media marketing in growing healthcare industry,2014,International Journal of Applied Engineering Research,V-9,I-22,P-7448-7456

21. Loganathan R., Pavithra J.,Consumer perception towards private label brand over other brands in super markets and hypermarkets,2014,International Journal of Applied Engineering Research,V-9,I-22,P-7355-7360

22. Kerinab Beenu G., Pavithra J.,Tradeâ€"off between liquidity and profitability in logistics industry,2014,International Journal of Applied Engineering Research,V-9,I-22,P-7398-7401

23. Kerinab Beenu G., Pavithra J.,A study on the prospective consumerâ€(M perception towards utility cars in Chennai city,2014,International Journal of Applied Engineering Research,V-9,I-22,P-7526-7531

24. Pavithra J., Dilli Babu P., Ambuli T.V.,A study on budgetary control at Maruti Service Masters, Chennai,2014,International Journal of Applied Business and Economic Research,V-12,I-2,P-151-161

25. Pavithra J., Dilli Babu P., Ambuli T.V.,A study on customer satisfaction of retro Garments Pvt Ltd, Chennai,2014,International Journal of Applied Business and Economic Research,V-12,I-2,P-381-391

26. Kerinab Beenu G.H., Pavithra J., Senthilmurugan P.,A study on the influence of promotional activities for TATA ARIA among consumers in Chennai,2014,International Journal of Applied Engineering Research,V-9,I-22,P-7572-7578

27. Vijayaragavan S.P.,An investigative expert that's general FBG sensors, International Journal of Mechanical Engineering and Technology,V-8,I-8,PP-1500-1505,Y-2017

28. Vijayaragavan S.P.,Equalization routing protocol for Wi-Fi sensor strategy,International Journal of Mechanical Engineering and Technology,V-8,I-8,PP-1662-1666,Y-2017

29. Karthik B., Kiran Kumar T.V.U., Vijayaragavan P., Bharath Kumaran E.,Design of a digital PLL using 0.35 $\hat{\mathrm{I}}^{1 / 4} \mathrm{~m}$ CMOS technology,Middle East Journal of Scientific Research,V-18,I-12,PP-1803-1806,Y-2013

30. Kanniga E., Selvaramarathnam K., Sundararajan M.,Kandigital bike operating system,Middle - East Journal of Scientific Research,V

31. Jasmin M., Vigneshwaran T., Beulah Hemalatha S.,Design of power aware on chip embedded memory based FSM encoding in FPGA,International Journal of Applied Engineering Research,V-10,I-2,PP-4487-4496,Y-2015

32. Jasmin M.,Optimization techniques for low power VLSI circuits,Middle East Journal of Scientific Research,V-20,I-9,PP-1082-1087,Y-2014

33. Jasmin M., Vigneswaran T.,Fuzzy controller for error control of on - Chip communication,2017 International Conference on Algorithms, Methodology, Models and Applications in Emerging Technologies, ICAMMAET 2017,V-2017-January,I-,PP-1-5,Y-2017

\section{AUTHORS PROFILE}

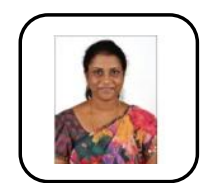

Magdalene Peter,Assistant Professor ,Department of MBA, Bharath Institute of Higher Education and Research, Tamilnadu, India

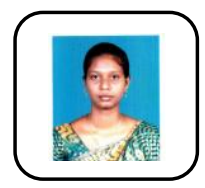

Fabiyola Kavitha, Associate Professor ,Department of MBA, Bharath Institute of Higher Education and Research, Tamilnadu, India

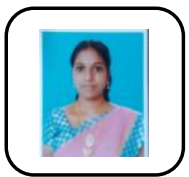

Mary Linda, Assistant Professor ,Department of CSE, Bharath Institute of Higher Education and Research, Tamilnadu, India 